\title{
BEyond MutabiLITY AND CHANGE. TRANSLATING JOYCE'S ULYSSES: A STUDY IN AMBIGUITY
}

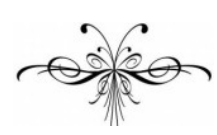

\section{ENRICO TERRINONI}

\begin{abstract}
The present paper addresses the issue of translating (lexical, syntactic, semantic) indeterminacy and ambiguity, in the author's 2012 re-translation of Joyce's Ulysses which comes in the wake of Giulio De Angelis's canonic 1960 Italian translation. Spanning a broad range of translation theories and arguing from the vantage point of a transformational aesthetics in translation, the essay shows on a series of textual examples focusing on cases of syntactical ellipses, multiple allusion, graphic indeterminacy (lack of punctuation), by what strategies the new and De Angelis's previous translation elicit the Italian reader's creative participation, emulating the micro and macro economy of the Joycean text.
\end{abstract}

Keywords: Indeterminacy; Ambiguity; Reader's response; Allusiveness; Ulysses.
Resumo: Este artigo trata da questão da tradução de indeterminações e ambiguidades (lexicais, sintáticas, semânticas) na retradução de 2012 deste autor do Ulysses de Joyce, que surge na esteira da tradução canônica de Giulio De Angelis, de 1960. Perpassando uma ampla gama de teorias da tradução e argumentando do ponto de vista privilegiado de uma estética da transformação que ocorre na tradução, o ensaio revela, por meio de uma série de exemplos textuais que enfocam casos de elipses sintáticas, múltiplas alusões e indeterminação gráfica (ausência de pontuação), através de quais estratégias a nova tradução e a de De Angelis evocam a participação criativa do leitor italiano, emulando as economias micro e macro do texto joyceano.

Palavras-chave: Indeterminação; Ambiguidade; Respostas dos leitores; Propriedade da alusão; Ulysses.

$\mathrm{S}$ ir Nicholas L'Estrange has a curious anecdote about translation, involving Shakespeare and Ben Jonson. In the mid-seventeenth century story, Shakespeare was godfather to one of Jonson's children, and had been thinking for some time about what to give the kid as a present. The established tradition being that godchildren would be given silver spoons, Shakespeare says to Ben Jonson, I'll give him a "douzen good Lattin Spoones, and thou shalt translate them". ${ }^{1}$ Latten being slightly less valuable than

\footnotetext{
${ }^{1}$ Anecdotes and Traditions, printed for the Camden Society, London, 1839, 2.
} 


\section{ENRICO TERRINONI}

silver, the implication here is that, since Shakespeare has "small Latin and less Greek", as Ben Jonson famously wrote, he will produce cheap quality literature, which Jonson can then improve through translation, that is, through transformation for the better.

This use of the verb "to translate" is somehow confirmed in Shakespeare also by a funny passage in As You Like It (5.2), when the jester Touchstone, in warning William to refrain from courting his beloved Audrey, says to him: "I will kill thee, make thee away, translate thy life into death, thy liberty into bondage". 2

Translation is transformation, then, and if in the first anecdote it was a change for the better, here it is a change for the worse. Let me complete the picture by telling a third story of my own.

In the summer of 2010 I spent a few days in a famous seaside resort in Italy. Sitting at my table in a cheap restaurant, I was in the mood for some fish, and saw on the menu that they had fritto misto di mare, that is, "mixed fried seafood". What captured my attention in the bilingual menu was the uncanny beauty of the English translation of this wonderful dish, which read: "Mixed Fried Sea"! What a charming rendition, I thought. How enchanting! Frying up a bit of Indian Ocean, some salty Dead Sea, and a sprinkle of Mediterranean, perhaps. Unfortunately, the only fried seas I knew then had been the poor waters of the Gulf of Mexico, when some genius over in America decided to set on fire the tons of barrels of oil spilled by BP after the famous disaster.

All this shows that not only is translation transformation, but also that in the shift from one thing to another, something changes that can affect both the aspect and the nature of what is translated, that is, the message. And this, because translation is all we unconsciously do whenever we communicate. Moreover, it is something we start doing as soon as we come into being. A very basic example of natural translation is the way toddlers translate impulses into funny noises.

To translate means to transform, then, but also to change a thing's positioning - from the Latin transferre, to bring beyond. Translation is to go beyond, and to bring oneself there too. I'm going back to the basics, here, at the risk of seeming naïve, for I think that, despite some highly sophisticated trends in recent translation theory, translation is still a very down-to-earth affair. In what follows, taking my recent translation of Ulysses as a pretext, I will not be speaking of translation as negotiation, but of the negotiation of translations, their adaptability to the market, and eventually the fact that they are produced and exchanged in an economically guided context - that is, for money.

The idea of exchanging knowledge in this way is akin to communication. Hence to translate also means to make common. It is useful, here, to go back to what one of the first "modern" translators, John Florio, thought of his job. In his translation of Montaigne's Essays, published in 1603, in a disclaimer curiously entitled, "To The Courteous Reader", he says: "Shall I apologize translation? Why but some holde [...] that such conversion is the subversion of Universities [...] my olde fellow Nolano tolde me, and taught publikely, that from translation all Science had it's of-spring [...]". ${ }^{3}$ It is interesting here that this quite revolutionary view is attributed to Florio's (and Joyce's) friend Giordano Bruno, the No-

\footnotetext{
${ }^{2}$ Shakespeare, William. The Arden Shakespeare. Complete Works (London: Methuen), 185.

${ }^{3}$ An online edition of Florio's Montaigne translation is available through Renaissance editions at http://www.uoregon.edu/ rbear/montaigne/index.htm
} 


\section{BEYOND MutABILITY AND CHANGE}

lan. Translation is thus a type of conversion that could lead to subversion. Florio goes on arguing that translation is "learning made common", 4 and, I would add, this is why sometimes it is under attack: because it is a democratic affair. For Florio "learning can never be too common," and this leads to his powerful defense of translation by employing a nice metaphor: people are jealous of their knowledge just as they would be of their fiancée. This is why, quite understandably, one must admit, people do not want knowledge to become "a prostitute". Florio's response to such an argument is as follows: "this Mistresse is like ayre, fire, water, the more breathed the clearer". 6

Translation has to be then most accessible for Florio, and one easily sees how this can in fact alter the nature of the original thing, in some cases. What do we do, then, when we are dealing with complex texts? Do we really have to simplify them in order to improve their readability?

Unfortunately, as I was saying before, when translation becomes something exchanged for money - that is, when it enters the economic dynamics of the publishing industry - the pressures to make "learning common" are strong. In general, one might agree with Anne Paterson's suggestion that "[a]ll commercial (as opposed to academic) translators are aware of strong pressures to adapt and update the source text, as well as 'just' translate it [...which is] only one aspect of what editors want more than anything else: readability - or, really, popular appeal. 'Make this book readable' they urge the translator.",

The question is, how to respond to this call, what to answer publishers and editors who are demanding more and more readability in translated texts. Simplified translation is akin to adaptation, and those who find some common ground between translation and adaptation do have a point. Allan Turner, for example, contends that "[t]ranslation can be seen as just one of the ways in which a literary text can be rewritten in order to make it available to a new readership in a new form". 8 This implies that "[t]he work of the translator may be compared to that of the musical arranger who rewrites a piece for a different instrument or group of instruments." " He offers the example of Liszt, "a most assiduous arranger for the piano [...] who used his technique partly to explore new sonorities of the instrument, and partly to make known the music of other composers before sound-recording could bring orchestral works within everyone's reach". ${ }^{10}$ Liszt, in fact, transcribed Beethoven's symphonies.

The question is whether translation might be considered to be so similar to adaptation and arrangement that we are indeed justified in simplifying difficult texts to reach wider audiences. The answer lies in the very nature of translation, which leads to another crucial question: can anything be read that is not translated? Though the adjective "translated" means "re-read and re-written", translating is not just a matter of reading and writing. It is indeed a modality of privileged

\footnotetext{
${ }^{4}$ Ibid.

${ }^{5}$ Ibid.

${ }^{6}$ Ibid.

7 Anna Paterson, "Translation as Editing?" In World Literature Today, Vol. 80, No. 6 (Nov. Dec., 2006), 51-54: 53.

${ }^{8}$ Allan Turner, "Translation and Criticism: The Stylistic Mirror", in The Yearbook of English Studies, Vol. 36, No. 1, Translation (2006), 168-176:168.

${ }^{9}$ Ibid., 168.

${ }^{10}$ Ibid., 169.
} 


\section{ENRICO TERRINONI}

reading, but it involves the effort to change a thing's positioning across a cultural space. Such a shift implies a transmutation of the very nature of the linguisticallyand culturally-shaped object/event to be moved.

Translation always speaks of movement, but it is a movement located in an invented past we call "present". Can change and movement ever be photographed and captured in a text? If texts, like dreams, weren't slippery and mutable stuff, we wouldn't have too many problems in translating them. The issue at stake here is, words do not have fixed meanings, as Eugene Nida taught us years ago, and texts are open to interpretation, whatever degree of fixity they might be said to have.

Having said this, I think it is time to go back to my pretext, the masochistic enterprise I was involved in for the past few years: translating what I myself consider an untranslatable text, a book to which I devoted my long gone youth, and one that I still enjoy reading in English and would never want to see translated, Joyce's Ulysses. The book has been taken to be a prototype of the open text; but, what exactly is an open text? Are not all texts open in some way, since we all read them from different angles? Open textuality goes hand in hand with the concept of ambiguity, which is in turn related to those of plurivocity, semantic multidimensionality, polyphony: in a word, heteroglossia. Before attempting to tread upon such slippery ground, I wish to reflect briefly on this crucial question: why translate Ulysses?

An answer would be: why not? In fact, a translator almost always works for at least one of the following reasons: money or academic recognition. Unfortunately, the scenario is much more complicated when it comes to the odyssey of translating a monster book like Ulysses. In our present, translations of the great book exist in almost all Western countries. Some are more authoritative than others, but all challenging in their own ways. As for Italy, we have a somewhat classical translation, done by Giulio De Angelis in 1960. This translation is known as the "authorized one", which is enough to scare anyone attempting to produce a new version of Joyce's work.

Referring to the "authorized translation", an Italian journalist recently wrote: "mandarla in pensione potrebbe essere meno semplice del previsto" - that means "to send it to the retirement home might be easier said than done". Such a foolish remark starts from a very wrong assumption, namely, that new translations are meant to replace the old ones, just like new lovers replace old husbands, or shower boxes replace taking a bath in the river. No translator - not me, anyway wants to send "authorized" translations to the retirement home. Translations simply do not work this way. Rather, like with lovers, the more the better.

I said that to translate is a rather democratic affair, and rightly so in its attempt to make books "readable", so to speak, by people who otherwise would be cut off from them. This implies a secret wisdom, which is inscribed in the history of communication: in order to make contact with "others we know not of", as Hamlet would say, we need to share fully or in part, the same medium. This is why many translations of the same text will no doubt enrich our knowledge, but also our own awareness of the world, or rather, the possible worlds that surround us.

In addition to this, while one can safely assume that a text, materially/physically speaking, stays almost the same over the years, its reception does not, for the cultural horizon and the expectations of its readers change in time. The 


\section{Beyond MutaBiLity AND CHANGE}

good thing about translations is that the text does not stay the same over the years. It changes, for language changes; it gets modernized sometimes, or it becomes more exact, and philologically accurate, as scholarship goes on. All such changes create new worlds, they open up new interpretive possibilities, and make the text new over and over again.

With this philosophy in mind, my Calvary started a few years ago when I accepted the offer of a commercial publisher to produce a new translation of Ulysses. After little thinking I said "yes", though my "yes" was even less resolute than Molly's. The book was going to be out straight in paperback, and it was to be an annotated student edition. The series in which it would have been published had a very specific target, that of young readers and university students. Now, the question whether translators should be worried or not about their targets is an interesting one. When you translate a book you shouldn't be thinking about how to make it easier for your readers to actually read the thing. But, the Italian case is, as often happens, quite unique. In fact, though our previous translation was in many ways well-done, and though it certainly fits in with the cultural climate of the time (it being published more than 50 years ago), it is undoubtedly not very readerfriendly now, so to speak.

Moreover, the previous translator had a very different approach to the book from mine - he read it differently, I should say. His rendering often has an archaic flavour to it, even when the language in Ulysses is colloquial and the register quite low. The general tone of his work is always much elevated, which totally jars with my own take on the text, a book I see as a comic work, and a very good one at that.

I wish to comment briefly on the very beginning of my translation ${ }^{11}$ for the simple reason that, in a country like Italy which is "founded upon authority", I am in the difficult position of one who is facing quite an established authority when it comes to Joyce's works in translation. The previous translation still enjoys the status of a canonical work, and its incipit is known by heart by many of those who love Joyce and/or devote their lives to the study of his great book.

Stately, plump Buck Mulligan (1.1)

Statuario, il pingue Buck Mulligan (I/T 33)

Solenne e paffuto, Buck Mulligan (I/DA 5)

My incipit is radically different from the one chosen by my predecessor. First of all I keep the punctuation, a crucial aspect to the interpretation of the text, for it allows us to see the adverbial function of the first word "stately", which is of course obviously an adjective. The Oxford English Dictionary lists its use also as an adverb, though not in recent times. There's a great difference in quality between the two adjectives describing Mulligan. While the first also comments on his character, the second mainly focuses on the man's physical appearance. The previous translation, by canceling the comma, puts the two items in the same position. Lexically speaking, both our choices of adjectives, though different, are somewhat equivalent. The difference is the way I present the second, "plump". In

\footnotetext{
${ }^{11}$ Joyce, James, Ulisse, trad. E. Terrinoni, rev. C. Bigazzi (Roma, Newton Compton, 2012). The text will henceforward be parenthetically referred to in the text as (I/T).
} 


\section{ENRICO TERRINONI}

fact, I am obliged to introduce an article there - il pingue - and this I do mainly for a cultural reason, and one linked to literary history and to the way I think Joyce is presenting Mulligan. I invite you to make a connection here with a line in the first part of Henry $I V$, where Falstaff says to Henry: "banish plump Jack and banish all the world". If we bear in mind the "note of banishment" Stephen speaks of in "Scylla and Charybdis", we might be tempted to see our plump Buck as a modern version of Shakespeare's plump Jack. This is reinforced in "Scylla and Charybdis" by another description of the jester Mulligan and his "well-kempt head". Though Falstaff is no jester, his role according to many was often impersonated by Will Kempe (well-kempt?). Once I made up my mind that Joyce is inaugurating Ulysses not with a predictable reference to serious Hamlet, but with a totally unpredictable reminiscence of plump Jack, I was forced by the rules of Italian grammar to insert an article before the adjective, so my "plump Buck" became il pingue Buck. I do not expect Italian readers to understand on the spot what Joyce is doing- or rather, what I am inventing - here, and this is why my first footnote in the book is one-page long. A very final comment is the possibility I had, a possibility translators are seldom afforded, to choose terms that even phonically resemble those in the original - Statuario: "Stately", pingue: "plump" - but this was just damn luck.

So when I started, I knew not what I was going to do, but I was pretty well aware of what I was not going to do, that is, to produce a text which would end up pushing readers away from the great book. So I tried, as far as possible, to stress the humour of Ulysses, and this I could often achieve in Italian by using lower registers than those employed in the previous translation.

However, were I asked a very stupid question like "how do you translate Ulysses?" I still would not know what to answer. Ulysses is, in fact, in my view, a "plural" text, if I am allowed the adjective, plural as the universe, as the Portuguese poet Fernando Pessoa would say. It is even more plural when it gets translated, for as Borges said, an original text can sometimes be unfaithful to its translation. ${ }^{12}$ Of course, there is no room for faithfulness or unfaithfulness in translation, for translation is always rewriting and "re-languaging" 13 and a work like Ulysses gives us the opportunity to test this plurivocity of the language, used in interconnection with the multicultural nature of the universe described by Joyce in so much detail.

Each episode has its own technique, and some have many more than one, and the styles used, mimicked or mocked by Joyce are numerous. Translators have to be aware of such mutability of the language, and it goes without saying that they do not have to aspire to producing the definitive, or authoritative text, but rather, a rendition that should be as open as possible, as ambiguous as possible, as transient and unstable as possible.

Since translation is always in balance between rendering and surrendering, one has to admit that with Ulysses, many times one is forced to face a decision between a number of options, all possible because all contained in, and suggested by, Joyce's text. A good translation strategy with Ulysses would be an "in-

\footnotetext{
${ }^{12}$ Quot. in Sergio Waisman, Borges and Translation. The Irreverence of the Periphery (Cranbury, NJ: Associated University Presses, 13)

${ }^{13}$ See Jolanta Wawrzycka, "Tell Us in Plain Words": Textual Implications of Re-Languaging Joyce", in Joyce Studies in Italy, vol 10, edited by Rosa Maria Bosinelli and Ira Torresi (Roma: Bulzoni, 2007).
} 


\section{BeyOnd MutaBiLiTy AND CHANGE}

clusive" one. Knowing this, I always went for the polysemic option, for the most ambiguous rendition, knowing that this would make way for new interpretations of the text.

As an Italian translator, I was luckier than many in this, for it seems to me that Joyce sneakily drops in his work many hints that may sound very familiar to Italian readers. In several places in Ulysses, especially in "Oxen of the Sun", but also in many of Bloom's unfinished sentences, one literally feels that the English Joyce is playing with is modelled on Italian syntax, and this allowed me to play in turn with language and create new interpretive patterns. This happens also in "Penelope" where my Italian attempts to break the rules of our language just as Joyce's English challenged and defeated the strictures of "his". In all cases, my strategy was always guided by the awareness that readers should have the last word, and an ambiguous translation helps readers feel empowered to have their own say.

This plural translation strategy was somehow supported by the way in which I decided to work. At first I worked more or less chronologically, from "Telemachus" to "Penelope". However, the various revisions afterwards were conducted, so to speak, by way of associations. In fact, Ulysses is a book in which, as you go on reading, you gain much knowledge on what came before; and the very habit of Joyce of going back to the episodes till the very last minute, encouraged me to rewrite them continuously, as I went back to my translations to revise them in the light of what I was gradually discovering. In this way, my translation is both teleological and random, or rather, it teleologically shows respect for the arranged randomness of the book. I made a point of turning my translation into a "retrospective arrangement" of Joyce's work.

This methodical randomness which might seem to imply a certain degree of freedom in the translator's method, cannot be easily reconciled with the silent rules and regulations of the translation market. What do we do, then, when our commercial publisher contracts us to translate for the market an overtly ambiguous and methodically random text? The problem is, writers like Joyce are not "normally" translated by "normal" translators. They are often translated by academics who are notorious for having little grasp of the commercial dynamics of the translation market. They sometimes work without a publishing contract, or on a fellowship.

Mine is a clear case of translational schizophrenia, for I happen to be an academic but one that translates for the market. My decision to work for the market comes from the awareness that in Italy Joyce's great book is little read by common readers, and this is probably due also to an excess in academicism that surrounds the book's reputation.

Anyway, with Joyce, as with a multitude of so-called open texts, translators need to adopt a multiplicity of approaches that can eventually yield results quite distant from what the translation market requires in terms of readability. The task of translators should naturally differ from the one imposed on them by the market; but with Joyce I feel we need at the same time to respond to the need for the democratization of his works without simplifying them, so to speak.

Joyce's Ulysses, a champion of heteroglossia, defies translation attempts exactly through its plurivocal and ambiguous translative possibilities. Unfortunately, it is not the ideal text to translate for money. In fact, what the translation industry in the West often requires is to try and avoid ambiguity in all possible 


\section{ENRICO TERRINONI}

ways, and ambiguity is the essence of Ulysses. Publishers must have marketoriented editorial policies, and translation is more often than not subjected to editorial revision, which is itself an external, ideologically-guided attempt to spot ambiguity in order to get rid of it. Editorial revision seems to be informed by the commercial need to produce plainly readable and unambiguous texts that can be consumed as quickly as possible, in order to minimize the impact of their potential hermeneutic openness.

Hermeneutic openness does not sell. Open texts such as Ulysses, whose very grammatical substructures defy exegetic normalization, demand a change in the relations between translators and publishers/editors, in that they cannot but call for the inclusiveness of ambiguous translations. The practice of translating Ulysses shows that the only translation of an open text is an open translation, always in balance between textual fluidity and changeable interpretations.

"Generalist translators" - people who work in and for the market, and who take the "task of the translator" as a synonymous phrase for "a way to make a living by translating books" - normally disregard the possible implications of a concept such as "open translation". Translators have pragmatic priorities. As (re)creators, they have to take into account their audience in terms of readership. They act under market conditions. Readers, who are often also buyers of books, have expectations about authors, and in the case of books in translation, it is ultimately up to translators to give an adequate response to such expectations. However, as Declan Kiberd argues, the difficulty of Joyce's great book is based on the "desire of a radical artist to escape the nets of the market", ${ }^{14}$ which somehow obliges translators, through the adoption of mutable translative strategies, to produce versions of the book that do not meet either the expectations of common readers, or those of publishers in terms of readability

The heterodox nature of Joycean texts often forces translators to prefer case-focused strategies to general theories about how to do their job. This might sometimes imply a shift in priorities, according to the peculiarities of the single stretches of discourse under consideration, so paving the way for the concept of translation as re-writing. Borges contends that translators have literary habits that will turn out to be more important than any chosen policy of interpretation or faithfulness, ${ }^{15}$ and this complicates matters further.

As we know, losses are the rule in translation. However, sometimes losses turn into gains. Though spurious, those gains, rather than providing clarifying tools, sometimes open up new hermeneutic possibilities, and this happens with the reproduction of mistakes, for example.

Translation is then a trans-modal journey that clearly involves a change in the thing to be transferred. Here considerations about ambiguity play a major role. According to Empson, a text, a sentence, a phrase, is ambiguous when "a word or grammatical structure is effective in several ways at once", ${ }^{16}$ so ambiguity can be "indecision as to what you mean, an intention to mean several things, a

\footnotetext{
${ }^{14}$ Declan Kiberd, Ulysses and Us. The Art of Everyday Living (Faber, London, 2009), 25

15 Jorge Luis Borges, "The Translators of the Thousand and One Nights." In Selected NonFictions, edited by Eliot Weinberger. Tr. Esther Allen, Suzanne Jill Levine, and Eliot Weinberger (New York, Viking, 1999), 34-48.

${ }^{16}$ Empson, William. Seven Types of Ambiguity (London: Chatto \& Windus, 1930), 2.
} 


\section{Beyond MutaBiLity AND CHANGE}

probability that one or other or both of two things has been meant, and the fact that a statement has several meanings". ${ }^{17}$

To approach a possible conclusion, let us try to give an answer to this crucially summarizing question: whenever translators need to reproduce their own interpretation of a text whose meaningful message gets diffracted into innumerable semantic subsystems, what do they have to do in order to create "readable works" that will not alienate readers?

With Joyce, as with a multitude of so-called open texts, translators might achieve results that are quite distant from what the translation market requires in terms of readability and plainness of versions. While according to the market, the task of the translator should be to reproduce a text always with an eye at communication, the translators' own goal is often to (re)create the best possible "second hand" text, in terms both of effects produced and information conveyed. By mediating between tasks and goals, translators always aspire to achieve a trade-off between the aesthetic and the semantic. And yet, such a balance is always subject to the translator's own interpretation of texts. The problem is, some texts clearly show impatience with yielding single meanings, or even simple readings. On a purely textual level, this is particularly true of puns, quotes, sound-centered passages, grammar mistakes, grammar oddities, and so on. All such issues theoretically require "non-conformist" translations that might actually sound "odd" - or defamiliarized, if you like - in the target language, just as they do in the source text.

The translation market naturally goes the opposite way, encouraging normalization and strategies whose final aim is to tame, if not to put down, the explosive potential of disruptive texts, such as those that defied canonical traditions, literary models, and ultimately, readers' expectations.

Let me end now by reflecting on what, in this view, was possibly among the most difficult sections of the book to translate, Molly's final monologue. The silently "oral" style of the chapter forced me to make some extreme decisions on several levels - typographical, lexical, syntactic, and finally musical - which resulted, I believe, in producing a text as defamiliarizing for the Italian reader as the original episode is, or rather was, for the eye and the ear of the English-speaking reader.

"Penelope" is the ultimate conclusion of a narrative which disrupts the structures of the English language and questions the stability of our own literary expectations. This is why in the final chapter a translator is allowed to take some risks. The way it looks, graphically, strikes one as totally unusual, and this is mainly due to the absence of apostrophes which leads in turn to the fusion of words. While such numerous instances often produce neutral results (mustnt, wouldnt), in some cases the new words we have also make sense in a different way. This happens, for instance, with he'll that without the apostrophe becomes hell, or we'd that without the apostrophe becomes wed. Generally speaking, the impression is of a type of speech not too influenced by cultural superstructures, a speech that appears to be very direct and straightforward. The mistakes Molly makes are mainly lexical, but they are not that important. What is relevant is the rapid flow of words that chase each other until they finally end up being joined together. The sense of rapid, uncoordinated, and yet supremely logical speech tells

\footnotetext{
${ }^{17}$ Ibid., 15.
} 


\section{ENRICO TERRINONI}

us a lot about this text being a specimen of oral literature. What is properly written in the episode is actually just transcribed, and the effort has to be to recreate such speed in translation, which is ultimately the speed of thought. This is why Molly's mistakes are not that important, for their function is not to tell us that she was illiterate or something to that extent. Here it is her brain that is speaking, her instinctdriven feelings get mixed up with her rationalizations, and this rapid flux has to be let flow rather than captured and stopped.

I kept the absence of apostrophes in Italian, which happened to produce similar effects. The new words are just fusions of other words originally divided by apostrophes, but some suggest new meanings, like d'anni ("of years") which without the apostrophe becomes danni ("damages") (I/T 729) ${ }^{18}$ I wish now to give an example of how I tried to reproduce Joyce's technique of conflating words to create new ones, which work in new ways in their new co-texts, while also reminding the reader of their original meanings. In "Penelope" we find sentences like "I hope hell come on Monday" ( $U$ 18.332), which could be read both as "I hope he'll come on Monday," and "I hope, hell, come on Monday!" Another similar example would be a sentence such as "till he half faints under me hell write about me lover" ( $U$ 18.1364). This could be read in its proper co-text, especially in the light of the words that follow the sentence - which are "and mistress publicly" ( $U$ 18.1365) - or in the following way: "till he half faints under me, hell! Write about me, lover!" In other words, the idea of conflating words by deleting apostrophes becomes a way to say more things at the same time, which is another version of Empson's ambiguity. Something similar happens in my translation when I use, for example, the word cera ("wax") instead of c'era ("there was"). Here is an instance of how this works in Italian: $O$ no cera la lozione per il viso che o finito ieri (I/T 713). This translates the original "O no there was the face lotion I finished the last of yesterday" ( $U$ 18.458). The English here is not too ambiguous; as clarified in what follows, the ambiguity I created in Italian compensates for other places in my translation in which I could not reproduce the original text's openness. The passage can be read mainly in two ways, that there was the face lotion, or that the face lotion was wax. Now, it can be sensibly argued that it might not be too easy to find women around who put wax on their faces, but in order to understand the pun, one has to consider that in Italian we have a word, cerone (despite its morphology, it does not mean "big wax"!), which translates into "greasepaint". We also have the expression avere una brutta cera, which would literally translate into "to have a bad wax", but which actually means "to have an unhealthy look".

Another feature of my text which depends on the choice of having got rid of apostrophes is the absence of the letter " $h$ " in the forms of the present of verb avere" ("to have"). In this way, the forms ho, ha, hanno (i.e. "I have, s/he has, they have") become $\dot{o}$, à, ànno, with the use of unusual accents which I believe add a very defamiliarizing touch to the text. These forms have been employed in the past mainly by avant-garde writers, like Carlo Dossi for example; but, more importantly for my interpretation of the "Penelope" episode, grammarians consider them "people's spellings", used mainly by not too educated persons in the first half of the twentieth century and before. In this way, the readers of my version of

\footnotetext{
18 Joyce, James, Ulisse, trad. E. Terrinoni, rev. C. Bigazzi (Roma, Newton Compton, 2012), 729.
} 


\section{Beyond MutaBiLity AND CHANGE}

Joyce's Ulysses will encounter a Molly who is at the same time an avant-garde experimentalist and a "woman of the people", so to speak, and this is another instance of how I tried to reproduce ambiguity, although here on a cultural level, rather than on a linguistic one.

What I wanted to do, then, with "Penelope"- alongside producing a text which would be as estranging as the original, in my view - was to follow the rapidity of Molly's exuberant flow of words, which breaks its banks and sweeps away orthographical as well as syntactic rules, but at the same preserving the natural ambiguity of her speech. The aim was also to give the idea of an oral textuality, which is finally free from the restrictions and the constrictions of writing as we know it.

I wish to give two more examples of a, perhaps less complex, form of ambiguity which was nonetheless quite challenging to reproduce in translation, especially in the light of the fact that it had not been translated properly in the previous Italian version of Ulysses. From the reader's point of view, I would call it "hermeneutic ambiguity", for it creates new semiotic scenarios which are indeed the springboard for contrasting interpretations of the same text. The first occurs in a passage of "Telemachus" where Stephen thinks, "Chewer of corpses" (U 1.278). Though many readings of the text have it that here Stephen is thinking of his own mother, like when just a moment before "Ghoul" occurred to him ( $U$ 1.278), the case can be made for this passage to be a reference to Stephen himself. Cases like this are problematic in Italian because we, as a rule, have to make a clear morphologic distinction between feminine and masculine. In fact, the expression had been translated by my predecessor, Giulio De Angelis, as masticatore di cadaveri, ${ }^{19}$ which gives us straightforwardly the idea that Stephen is referring to himself. My translation keeps the original ambiguity by conflating the two terms into one single word "masticacadaveri" (I/T 39) which can be at same time masculine and feminine, so creating that semiotic change of scenario which gives way to two opposite, though coexisting, interpretations of the same text.

Another example of ambiguity - or rather, of my own efforts to recreate it in translation - comes from "Circe", and precisely from the place where Bloom "offers the other cheek" ( $U$ 15.1109) to Mrs Bellingham, who wishes to "vivisect him" ( $U$ 15.1105). Here the previous Italian translator had turned "cheek" into guancia (I/DA 1999: 640), with the primary meaning of "cheek" in mind, namely, "the fleshy part of either side of the face below the eye and between the nose and ear" ${ }^{\prime 2}$. In this way, De Angelis rightly locates the reference as an allusion to Luke 6: 29, but loses the ambiguity of the usage of this term in Ulysses, which also reminds us (especially in the light of the setting of the scene) to the other meaning of "cheek", namely "either of the buttocks". ${ }^{21}$ My decision to use the word chiap$p a$ (colloquial for the latter meaning of "cheek") is justified, I think, on two levels. First, I am aware of the ambiguity of the original term, and therefore have to reproduce it. Secondly, I know that, even though I am not using the right evangelical word, readers will recognize the reference all the same thanks to the rest of the sentence: my porge l'altra chiappa (I/T 457) echoes or rather, reflects as in a

\footnotetext{
${ }^{19}$ Joyce, James, Ulisse, trad. Giulio De Angelis, rev. Giorgio Melchiori, Carlo Izzo, Glauco Cambon (Milano: Mondadori, "I meridiani”, 1999), 15. The text will henceforward be parenthetically referred to in the text as (I/DA 1999).

${ }^{20}<$ http://www.thefreedictionary.com/cheek $>$

${ }^{21}<\mathrm{http}: / /$ www.thefreedictionary.com/cheek $>$
} 


\section{ENRICO TERRINONI}

glass darkly, the image of porge l'altra guancia, from the Italian translation of Luke 6: 29, giving it at the same time a somewhat blasphemous connotation which I also find in the original.

I wish to give a final example of how ambiguity in the text gives way to freedom of interpretation, thus requiring translative choices as open as possible. I am referring to one of the most discussed passages of Ulysses:

$$
\begin{aligned}
& \text { U.P.: up (8.257) } \\
& \text { P.U.: pu (I/T\&B 175) } \\
& \text { S.U.: su (I/DA 215) }
\end{aligned}
$$

I've always been disappointed by the lack of creativity which led my predecessor to translate this passage literally, a choice which makes no sense in Italian. My interpretation might sound a bit far-fetched, but I think that this case deserves some risk. My explanation - which of course required a footnote - draws on the legacy of religious and colonial contrasts in Ireland. As Gibbons has also pointed out, "UP" was the acronym of United Presbyterians - which makes sense here, I think, for the simple reason that the majority of protestants in Ireland, especially in the north, are Presbyterians. Those letters may also refer variously to "unionist" or "protestant". However, why would Mr Breen be so annoyed by this way of addressing him? We need to bear in mind that, especially in working-class areas of Dublin, the term "protestant" is still sometimes used as a sort of mocking way to address someone, or even as an insult. This said, I do believe that there are a thousand possible explanations of the "UP" instance, but my solution works also in another way. In fact, inverting the letters - PU: presbiteriani uniti or protestante unionista - I was also creating a nice insulting onomatopoeia, for the expression $p u$ stands here for the sound of someone who is spitting on the face of someone else. Furthermore, P.U.: pu can be read in Italian also as pupù, meaning poo. Finally, I do believe the "UP" in Ulysses might just be an abbreviation for "up your arse", and this is my final unheard cry for full interpretive freedom in translation!

Having said this, I think it is time to call for a new awareness of the translation process which would open the eyes of book readers/buyers and book publishers/sellers, starting from the undeniable truth that, translation being necessarily the basic communicative tool among peoples, it has to take notice of the fact that communication can sometimes be oblique, discordant, and take byways instead of main thoroughfares. Such new awareness has to create the conditions for a reflection on the new concept of "open translation", that will hopefully be applied in time not only to the so-called "open texts" but also to other works which, for one reason or another, yield themselves to different, multiple, and even contradictory interpretations and readings.

Enrico Terrinoni

enrico.terrinoni@unistrapg.it

Translator, PhD, Professor, University for Foreigners of Perugia 